\title{
Pengaruh Likuiditas dan Growth Terhadap Dividend Payout Ratio
}

\author{
Tuti Setiatin
}

Sekolah Tinggi Ilmu Ekonomi PGRI Sukabumi

tuti.setiatin@ stiepgri.ac.id

\begin{abstract}
ABSTRAK
Penelitian ini bertujuan untuk menguji bagaimana pengaruh likuiditas dan growth terhadap dividend payout ratio (DPR) serta menguji pengaruh likuiditas dan growth secara bersama-sama terhadap dividend payout ratio (DPR). Variabel likuiditas diukur dengan menggunakan Loan to Deposit Ratio (LDR), growth diukur dengan menggunakan Asset Growth, dan Dividend Payout Ratio menggunakan (DPR).

Populasi yang digunakan dalam penelitian ini sebanyak 55 perusahaan sektor perbankan yang terdaftar di Bursa Efek Indonesia periode 2013-2017. Sampel penelitian dipilih dengan menggunakan metode purposive sampling sehingga didapatkan 8 perusahaan sektor perbankan yang memenuhi kriteria. Pengujian hipotesis menggunakan analisis regresi linier berganda dengan $\alpha(5 \%)$.

Hasil penelitian ini menunjukkan bahwa likuiditas berpengaruh positif terhadap dividend payout ratio. Sedangkan Growth berpengaruh negatif terhadap dividend payout ratio. Serta likuiditas dan growth berpengaruh secara bersama-sama terhadap dividend payout ratio. Koefisien determinasi dari penelitian ini adalah bahwa $26,9 \%$ variasi dari variabel dependen dividend payout ratio dapat diprediksi dari kombinasi variabel likuiditas dan profitabilitas, sedangkan sisanya sebesar 73,1\% tidak dapat dijelaskan oleh faktor lain yang tidak dimasukkan dalam penelitian.
\end{abstract}

Kata kunci: Dividend Payout Ratio (DPR), Likuiditas, Growth

This research aims to examine the effect of liquidity and growth to the dividend payout ratio (DPR) and examine the effect of liquidity and growth together to the dividend payout ratio (DPR). Liquidity variables are measured using a Loan to Deposit Ratio (LDR), growth is measured using Growth Assets, and Dividend Payout Ratio using (DPR).

Population that use in this research is 55 listed banking sector companies in Indonesia Stock Exchange in the 2013-2017 period. The research sample have been selected by using a purposive sampling method to obtain 8 banking sector companies that met the criteria. Hypothesis testing uses multiple linear regression analysis with $\alpha(5 \%)$.

The results show that liquidity has a positive effect to dividend payout ratio. While Growth negatively affects to dividend payout ratio. Liquidity and growth together influence the dividend payout ratio. The coefficient of determination it can be concluded that $26.9 \%$ of the variation of the dependent variable dividend payout ratio can be predicted from a combination of liquidity and growth variables, while $73.1 \%$ can be explained by other factors not included in this research.

Keyword: Dividend Payout Ratio, Liquidity, Growth

\section{PENDAHULUAN}

Investasi dalam suatu perusahaan perbankan merupakan salah satu hal yang penting agar perusahaan dapat menjalankan kegiatan usahanya. Namun, aktifitas investasi merupakan aktifitas yang dihadapkan pada berbagai macam risiko dan ketidakpastian yang seringkali sulit diprediksikan oleh para investor. Untuk mengurangi risiko dan ketidakpastian yang akan terjadi, investor memerlukan berbagai macam informasi, baik informasi yang diperoleh dari kinerja perusahaan maupun informasi lain yang relevan seperti kondisi ekonomi dan politik suatu Negara. Baik 
informasi saat ini, masa lampau maupun informasi di masa yang akan datang yang merupakan hasil pakiraan nilai trend [1]. Informasi dari perusahaan lazimnya didasarkan pada kinerja perusahaan yang tercermin dalam laporan keuangan. Berdasarkan laporan keuangan, investor dapat mengatahui kinerja perusahaan dalam menghasilkan profitabilitas dan besarnya pendapatan dividen per lembar saham [2].

Tujuan utama seorang investor dalam menanamkan dananya yaitu untuk memperoleh pendapatan (return) yang dapat berupa pendapatan dividen (dividend yield) maupun pendapatan dari selisih harga jual saham terhadap harga beli. Namun tujuan investor ini kadang bertentangan dengan manajemen perusahaan yang dimana menimbulkan adanya masalah keagenan. Di samping itu manajemen sering mengalami kesulitan dalam membuat keputusan apakah laba yang diperoleh perusahaan pada akhir tahun akan dibagi kepada pemegang saham dalam bentuk dividen atau akan ditahan untuk menambah modal guna pembiayaan investasi di masa yang akan datang [3]. Oleh karena itu diperlukan adanya kebijakan tersendiri yang mengatur masalah dividen tersebut. Perusahaan perlu membuat kebijakan tentang besarnya laba yang akan dibagikan kepada pemegang saham atau biasa disebut Dividend Payout Ratio (DPR).

Dividend Payout Ratio (DPR) seringkali dikaitkan dengan signaling theory [4]. Teori ini menjelaskan suatu tindakan yang diambil oleh manajemen pada suatu perusahaan yang memberikan petunjuk kepada pemegang saham tentang bagaimana manajemen melihat prospek perusahaan. Para manajer sering kali memiliki informasi yang lebih baik tentang prospek dividen di masa depan dibandingkan dengan pemegang saham, sehingga jelas terdapat muatan informasi dalam pengumuman dividen [5].

Dividend Payout Ratio (DPR) yang berkurang dapat mencerminkan laba perusahaan yang makin berkurang. Akibatnya sinyal buruk akan muncul karena mengindikasikan bahwa perusahaan kekurangan dana. Kondisi ini akan menyebabkan preferensi investor akan suatu saham berkurang karena investor memiliki preferensi yang sangat kuat atas dividen. Sehingga perusahaan akan selalu berupaya untuk mempertahankan Dividend Payout Ratio (DPR) meskipun terjadi penurunan jumlah laba yang diperolehnya. Pada umumnya pihak manajemen tidak menyukai dan menghindari pemotongan atau pengurangan pembayaran dividen. Pembayaran dividen yang tinggi atau tetap memberian indikasi atau tingkat keuntungan perusahaan dimasa yang akan datang. Selain itu pembayaran dividen risikonya lebih kecil, karena lebih pasti dibandingkan dengan capital gain. Perusahaan yang membayar dividen dengan persentase yang lebih besar, dipersepsikan sebagai perusahaan dengan beta yang lebih rendah dibanding perusahaan yang membayar dividen dengan persentase yang lebih kecil [6]. 
Di Indonesia, fenomena atau realita Dividend Payout Ratio (DPR) yang terjadi pada perusahaan perbankan konvensional menunjukan adanya berbagai reaksi. Salah satunya yang terjadi pada tahun 2016, total dividen yang disetor bank BUMN kepada pemegang saham mencapai Rp 21,15 triliun atau tumbuh 29,4\% jika dibandingkan dengan tahun 2015 sebesar Rp 16,34 triliun. Dalam nilai relatif, rasio pembayaran dividen bank-bank pelat merah juga mencatat rekor tertinggi selama lima tahun terakhir dengan besaran berkisar 20\%-45\%. Pembagian deviden semacam ini sejatinya adalah peristiwa lumrah bagi perusahaan yang berbentuk perseroan. Modal perusahaan disokong oleh banyak pihak. Saat perseroan memperoleh laba, dividen diberikan kepada pemegang saham sebagai balas jasa atas modal yang sudah ditanamkan.

Namun, persoalan pembagian deviden khususnya untuk perbankan pada kali ini seolah agak 'luar biasa'. Ini terjadi karena Bank Indonesia (BI) mengusulkan adanya pembatasan pembagian dividen perbankan. Dalam pandangan BI, perbankan sering menyetor dividen dengan rasio yang besar tanpa mempertimbangkan kecukupan modal. Penilaian BI yang demikian itu memang masuk akal. Kinerja perbankan sepanjang 2016 agak merosot. Dari sisi hulu adalah melambatnya dana pihak ketiga (DPK). Hingga Desember 2016, DPK tumbuh hanya 8\% secara tahunan. Dari sisi hilir, kredit perbankan tumbuh 9\%. Keduanya lebih rendah dibanding tiga tahun sebelumnya yang mampu tumbuh dua digit. Konsekuensinya, LDR (Loan to Deposit Ratio) naik menjadi 94\%. Artinya, hampir seluruh DPK telah tersalur menjadi kredit. Dengan keterbatasan ruang gerak, perbankan pun masih terbelit kredit macet yang melebihi rasio 3\%. Imbasnya, saat mengalami kesulitan likuiditas, perbankan harus menutupnya dari modal sendiri. (https://www.beritasatu.com/investor/424265menyoal-pembagian-dividen-perbankan. html)

Selain fenomena di atas, dalam kenyataannya masih terjadi kenaikan dan penurunan mengenai Dividend Payout Ratio (DPR) . Berikut ini disajikan beberapa data Dividend Payout Ratio (DPR) perusahaan perbankan yang terdaftar di BEI tahun 2013 - 2017.Dividend Payout Ratio (DPR) perusahaan perbankan tahun 2013-2017

\begin{tabular}{|c|c|c|c|c|c|c|c|}
\hline \multirow[t]{2}{*}{ No } & \multirow[t]{2}{*}{ Kode } & \multirow[t]{2}{*}{ Nama Bank } & \multicolumn{5}{|c|}{ Dividend Payout Ratio (DPR) } \\
\hline & & & 2013 & 2014 & 2015 & 2016 & 2017 \\
\hline 1 & AGR0 & PT Bank Rakyat Indonesia Agroniaga Tbk & 0.20 & 0.10 & 0.19 & 0.19 & 0.38 \\
\hline 2 & BBCA & PT Bank Central Asia Tbk & 0.21 & 0.22 & 0.22 & 0.24 & 0.27 \\
\hline 3 & BBNI & PT Bank Negara Indonesia (Persero) Tbk & 0.30 & 0.25 & 0.25 & 0.35 & 0.35 \\
\hline 4 & BBRI & PT Bank Rakyat Indonesia (Persero) Tbk & 0.30 & 0.30 & 0.40 & 0.40 & 0.45 \\
\hline 5 & BJBR & Bank Pembangunan Daerah Jawa Barat dan Banten Tbk & 0.55 & 0.63 & 0.60 & 0.55 & 0.55 \\
\hline 6 & BMRI & PT Bank Mandiri (Persero) Tbk. & 0.30 & 0.25 & 0.30 & 0.45 & 0.45 \\
\hline 7 & BNBA & Bank Bumi Arta Tbk. & 0.25 & 0.25 & 0.25 & 0.25 & 0.26 \\
\hline 8 & BJTG & Bank Pembangunan Jawa Tengah Tbk. & 0.42 & 0.47 & 0.44 & 0.50 & 0.50 \\
\hline
\end{tabular}

Sumber : $\underline{w w w . i d x . c o . i d}$ (data diolah) 
Tabel diatas menunjukkan pembagian Dividend Payout Ratio (DPR) perusahaan perbankan tahun 2013-2017. Dapat dilihat bahwa terjadi kenaikan dan penurunan Dividend Payout Ratio (DPR), padahal perubahan dividen menjadi hal yang penting untuk dijadikan suatu tolak ukur bagi para investor dalam menanamkan modalnya di suatu perusahaan.

Menurut Fred Weston, menyebutkan bahwa rasio likuiditas merupakan rasio yang menggambarkan kemampuan perusahaan memenuhi kewajiban (utang) jangka pendek [7]. Artinya, apabila perusahaan ditagih, maka akan mampu untuk memenuhi utang (membayar) tersebut terutama utang yang sudah jatuh tempo. Likuiditas perusahaan merupakan pertimbangan utama dalam banyak keputusan pembayaran dividen [8]. Karena pembayaran dividen menunjukkan arus kas keluar, makin besar posisi kas dan keseluruhan likuiditas perusahaan, maka makin besar kemampuan perusahaan untuk membayar dividen. Likuiditas mempengaruhi daya tarik saham kepada investor. Investor mungkin membutuhkan lebih tinggi pengembalian yang diharapkan atas aset yang return sensitif terhadap likuiditas [9]. Dalam penelitian ini likuiditas di ukur menggunakan Loan to Deposit Ratio (LDR).

Faktor lain yang mempengaruhi Dividend Payout Ratio (DPR) adalah pertumbuhan. Pertumbuhan perusahaan menunjukkan pertumbuhan aset. Pertumbuhan perusahaan dalam penelitian ini diproksikan dengan Asset Growth. Murni dan Adriana [10] menyatakan bahwa pendekatan pertumbuhan perusahaan merupakan suatu komponen untuk menilai prospek perusahaan pada masa yang akan datang. Hal ini didukung dengan penelitian yang dilakukan oleh Janifairus dkk. [11] yang menyebutkan bahwa assets growth berpengaruh siginifikan terhadap Dividend Payout Ratio (DPR).

\section{KAJIAN PUSTAKA}

Menurut Darmadji dan Fakhruddin [12] dividen adalah laba perusahaan yang dibagikan kepada para pemegang saham baik berupa dividen tunai maupun dividen saham atas persetujuan Rapat Umum Pemegang Saham (RUPS). Menurut Horne dan Wachowicz, JR [8]: dividend payout ratio adalah persentase laba bersih yang dibagikan sebagai dividen maupun laba yang ditahan dalam perusahaan sebagai sumber pendanaan. Menurut Munawir [13] likuiditas merupakan salah satu alat yang dapat digunakan untuk mengukur keberhasilan suatu perusahaan yang dilihat dari seberapa besar kemampuan perusahaan dalam memenuhi kewajibannya. Suatu perusahaan dapat dikatakan likuid apabila perusahaan tersebut mampu melunasi kewajiban finansial jangka pendek maupun jangka panjang.

Salah satu ukuran rasio likuiditas yang digunakan untuk mengukur likuiditas perusahaan perbankan adalah Loan to Deposit Ratio. Menurut Kasmir [7] LDR adalah rasio yang mengukur sejauh mana kemampuan bank dalam membayar kembali penarikan dana yang dilakukan deposan 
dengan mengandalkan kredit yang diberikan sebagai sumber likuiditasnya. Semakin tinggi rasio ini maka semakin rendahnya likuiditas bank yang bersangkutan. Namun sebaliknya, jika semakin rendah rasio LDR maka semakin tinggi likuiditas bank yang bersangkutan. Rasio ini juga merupakan indikator kerawanan dan kemampuan dari suatu bank.

Riyanto [14] dalam teorinya mengemukakan bahwa makin cepat tingkat pertumbuhan suatu perusahaan, makin besar kebutuhan akan dana untuk membiayai pertumbuhan perusahaan tersebut. Makin besar kebutuhan dana untuk waktu mendatang untuk membiayai pertumbuhannya, perusahaan tersebut biasanya lebih senang untuk menahan "earning”nya daripada dibayarkan sebagai dividen kepada para pemegang saham dengan mengingat batasan-batasan biayanya. Dengan demikian dapatlah dikatakan bahwa makin cepat tingkat pertumbuhan perusahaan maka makin besar dana yang dibutuhkan, makin besar kesempatan untuk memperoleh keuntungan, makin besar bagian dari pendapatan yang ditahan dalam perusahaan, yang ini berarti makin rendah "dividend payout ratio"nya. Apabila perusahaan telah mencapai tingkat pertumbuhan sedemikian rupa sehingga perusahaan telah "well established", dimana kebutuhan dananya dapat dipenuhi dengan dana yang berasal dari pasar modal atau sumber dana ekstern lainnya, maka keadaannya adalah berbeda. Dalam hal yang demikian perusahaan dapat menetapkan "dividend payout ratio" yang tinggi.

\section{METODE PENELITIAN}

Metode kausal dipilih dalam penelitian ini karena dengan mengimplementasikan metode ini dapat menunjukkan secara sistematis pengaruh sebab-akibat antara variabel independen [15] yakni pengaruh likuiditas dan growth terhadap variabel dependen yakni dividend payout ratio.

Dalam penelitian ini bahwa data yang dipakai dengan menggunakan pooled data yakni gabungan data berdasarkan cross section dan time series, dimana pengambilan data dari luasnya objek dengan sejumlah periode observasi. Unit analisis yang digunakan untuk penelitian ini berupa perusahaan perbankan yang terdaftar di Bursa Efek Indonesia yang menerbitkan laporan keuangan, serta laporan tahunan dengan periode dari tahun 2013 sampai dengan tahun 2017.

Populasi yang digunakan dalam penelitian ini adalah perusahaan perbankan yang terdaftar di Bursa Efek Indonesia (BEI) selama periode penelitian yaitu dari tahun 2013 sampai dengan tahun 2017. Berdasarkan populasi tersebut nantinya dipilih sejumlah perusahaan untuk dijadikan sampel penelitian. Populasi dalam penelitian ini adalah sebanyak 55 perusahaan perbankan yang terdaftar di Bursa Efek Indonesia tahun 2013 sampai dengan tahun 2017

Pemilihan objek sampel penelitian dilakukan secara purposive sampling method, yang berarti populasi yang dijadikan sampel memenuhi kriteria-kriteria tertentu dengan memiliki tujuan yaitu mendapatkan sampel yang representatif sesuai dengan yang dibutuhkan dalam penelitian ini [16]. 
Adapun kriteria yang digunakan untuk memilih sampel pada penelitian ini adalah sebagai berikut:

1) Perusahaan termasuk dalam kategori perbankan yang telah terdaftar di Bursa Efek Indonesia dari tahun 2013 sampai dengan 31 Desember 2017.

2) Perusahaan perbankan yang terdaftar di Bursa Efek Indonesia yang menerbitkan baik laporan tahunan (annual report) maupun laporan keuangan per 31 Desember yang sudah diaudit selama periode pengamatan dari tahun 2013 sampai dengan 31 Desember 2017, serta memiliki laporan keuangan lengkap sesuai dengan data yang dibutuhkan dalam variabel penelitian.

3) Perusahaan yang membagikan dividen secara berturut-turut selama periode penelitian, yaitu tahun 2013 sampai dengan 31 Desember 2017.

Berdasarkan dari kriteria yang digunakan untuk memilih sampel pada penelitian ini, maka jumlah akhir sampel yang digunakan adalah sebanyak 8 perusahaan perbankan yang terdaftar di Bursa Efek Indonesia tahun 2013 sampai dengan 2017. Teknik analisa data dalam penelitian ini menggunakan analisis regresi OLS dan ujinya Simultan (F hitung) digunakan untuk mengetahui apakah semua variabel bebas yang dimasukkan ke dalam model mempunyai pengaruh serentak terhadap variabel terikat. Uji Parsial (t hitung) digunakan untuk menguji hipotesis secara parsial guna menunjukkan pengaruh tiap variabel independen (bebas) secara individu terhadap variabel dependen (terikat).

\section{HASIL DAN PEMBAHASAN}

Analisis Regresi Linier Berganda

Diperoleh persamaan regresi linier berganda sebagai berikut: DPR $=-0,628+1,223$ LIKUIDITAS 0,501GROWTH

Pengujian Hipotesis Secara Simultan (uji F)

Pengujian secara simultan X1 dan X2 terhadap Y diperoleh nilai Fhitung 12,094 dan sig 0,0000< 0,05 hal ini berarti Fhitung 12,094 > Ftabel 3,25 dan sig 0,0000<0,05 yang berarti bahwa $\mathrm{H}_{0}$ ditolak dan hipotesis diterima. Sehingga dapat disimpulkan bahwa likuiditas dan growth secara bersamasama memiliki pengaruh terhadap dividend payout ratio (DPR).

Nilai koefisien determinasi yang ditunjukkan dengan Adjusted $\mathrm{R}$ Square $\left(\mathrm{R}^{2}\right)$ sebesar 0,363 atau $36,3 \%$ hal ini berarti $36,3 \%$ variabel dividend payout ratio dapat dijelaskan oleh variasi dari dua variabel bebas yaitu likuiditas dan growth sedangkan sisanya sebesar 63,7\% dijelaskan oleh variabelvariabel lain yang tidak ada dalam model regresi dalam penelitian ini.

Sebelum dilakukan pembahasan mengenai hasil penelitian yang dilakukan, terlebih dahulu disajikan ringkasan hasil pengujian hipotesis sebagai berikut: 


\section{Ringkasan Hasil Pengujian Hipotesis}

\begin{tabular}{|c|l|c|c|c|c|}
\hline Hipotesis & \multicolumn{1}{|c|}{ Deskripsi } & B & F & Sig. & Kesimpulan \\
\hline 1 & $\begin{array}{l}\text { Likuiditas berpengaruh } \\
\text { terhadap dividend } \\
\text { payout ratio (DPR) }\end{array}$ & 1,223 & & 0.000 & Diterima \\
\hline 2 & $\begin{array}{l}\text { Growth berpengaruh } \\
\text { terhadap dividend } \\
\text { payout ratio (DPR) }\end{array}$ & $-0,501$ & & 0.021 & Diterima \\
\hline 3 & $\begin{array}{l}\text { Likuiditas dan Growth } \\
\text { secara bersama-sama } \\
\text { berpengaruh terhadap } \\
\text { Dividend Payout Ratio } \\
\text { (DPR) }\end{array}$ & 12.094 & 0.000 & Diterima \\
\hline
\end{tabular}

Sumber : Hasil Pengolahan Data dengan Software SPSS (Lampiran).

\section{Pengaruh Likuiditas terhadap Dividend Payout Ratio (DPR)}

Berdasarkan tabel mengenai hasil uji hipotesis pertama yang dilakukan menunjukkan bahwa likuiditas berpengaruh terhadap dividend payout ratio (DPR). Dengan demikian penelitian ini menunjukkan bahwa semakin besar likuiditas, maka dapat mempengaruhi dividend payout ratio (DPR). Hasil penelitian ini sejalan dengan teori keagenan bahwa konflik yang terjadi dalam keagenan tidak disukai oleh para pemegang saham karena hal tersebut akan menambah biaya perusahaan yang menyebabkan penurunan keuntungan dan dividen yang diterima pemegang saham [5]. Untuk mengatasi konflik antara manajer dan pemegang saham, dimana pemegang saham dapat mengambil keuntungan dari manajer melalui dividen yang dibayarkan, manajer mencoba mengatasi masalah ini melalui pembatasan pembayaran dividen. Dimana pihak principal yaitu pemegang saham akan merasa diuntungkan apabila perusahaan memiliki likuiditas yang tinggi, karena pihak principal akan terhindar dari risiko-risiko yang ditimbulkan perusahaan seperti ketidakmampuan perusahaan dalam membayar hutang yang dapat menyebabkan perusahaan mengalami kebangkrutan. Apabila perusahaan tidak mampu membayar utang-utangnya, tentu akan mempengaruhi keadaan keuangan perusahaan dan berakibat pada jumlah deviden yang akan dibagikan.

Hasil penelitian ini juga sejalan dengan teori yang dikemukakan oleh Fred Weston yang menyebutkan bahwa rasio likuiditas merupakan rasio yang menggambarkan kemampuan perusahaan memenuhi kewajiban (utang) jangka pendek [7]. Artinya, apabila perusahaan ditagih, maka akan mampu untuk memenuhi utang (membayar) tersebut terutama utang yang sudah jatuh tempo. 
Likuiditas perusahaan merupakan pertimbangan utama dalam banyak keputusan pembayaran dividen [8]. Karena pembayaran dividen menunjukkan arus kas keluar, makin besar posisi kas dan keseluruhan likuiditas perusahaan, maka makin besar kemampuan perusahaan untuk membayar dividen.

Hasil penelitian ini mendukung penelitian yang dilakukan oleh Baramuli [17] yang menunjukkan bahwa likuiditas berpengaruh signifikan terhadap Dividend Payout Ratio (DPR) yang berarti bahwa besar kecilnya dividen yang dibagikan dipengaruhi oleh likuiditas perbankan, dimana semakin tinggi likuiditas maka semakin tinggi Dividend Payout Rationya (DPR), begitu pula sebaliknya.

\section{Pengaruh Growth terhadap Dividend Payout Ratio (DPR)}

Berdasarkan tabel mengenai hasil uji hipotesis kedua yang dilakukan menunjukkan bahwa growth berpengaruh terhadap dividend payout ratio (DPR) namun memiliki hubungan yang berlawanan dengan dividend payout ratio (DPR). Dengan demikian penelitian ini menunjukkan bahwa semakin tinggi growth maka semakin besar kebutuhan dana perusahaan untuk kegiatan ekspansinya sehingga dividend payout ratio semakin rendah. Sebaliknya semakin rendah growth maka semakin sedikit kebutuhan dana sehingga dividend payout ratio semakin besar.

Hasil penelitian ini sejalan dengan teori yang dikemukakan oleh Riyanto [14] dalam teorinya mengemukakan bahwa makin cepat tingkat pertumbuhan suatu perusahaan, makin besar kebutuhan akan dana untuk membiayai pertumbuhan perusahaan tersebut. Makin besar kebutuhan dana untuk waktu mendatang untuk membiayai pertumbuhannya, perusahaan tersebut biasanya lebih senang untuk menahan "earning"nya daripada dibayarkan sebagai dividen kepada para pemegang saham dengan mengingat batasan-batasan biayanya. Dengan demikian dapatlah dikatakan bahwa makin cepat tingkat pertumbuhan perusahaan maka makin besar dana yang dibutuhkan, makin besar kesempatan untuk memperoleh keuntungan, makin besar bagian dari pendapatan yang ditahan dalam perusahaan, yang ini berarti makin rendah “dividend payout ratio"-nya. Apabila perusahaan telah mencapai tingkat pertumbuhan sedemikian rupa sehingga perusahaan telah "well established", dimana kebutuhan dananya dapat dipenuhi dengan dana yang berasal dari pasar modal atau sumber dana ekstern lainnya, maka keadaannya adalah berbeda. Dalam hal yang demikian perusahaan dapat menetapkan "dividend payout ratio" yang tinggi.

Hasil penelitian ini juga senada dengan penelitian yang dilakukan oleh Effendi dkk. [18] yang menunjukkan bahwa pertumbuhan asset growth berpengaruh negatif dan signifikan terhadap dividend payout ratio. Semakin tingginya asset growth akan semakin rendah kemampuan perusahaan untuk 
membayar seluruh kewajibannya membayar dividen kepada para pemegang saham. Hal ini disebabkan karena semakin besar proporsi aset yang digunakan untuk ekspansi perusahaan. Asset growth merupakan rasio yang menggambarkan pertumbuhan aset perusahaan dari tahun ke tahun.

\section{Pembahasan Likuiditas dan Growth Secara Bersama-Sama Memiliki Pengaruh Terhadap Dividend Payout Ratio (DPR).}

Berdasarkan tabel 4.9 mengenai hasil uji hipotesis ketiga yang dilakukan menunjukkan bahwa likuiditas dan growth secara bersama-sama memiliki pengaruh terhadap dividend payout ratio (DPR). Hasil pengujian secara simultan ini Hasil pengujian ini sesuai dengan teori bahwa likuiditas perusahaan merupakan pertimbangan utama dalam banyak keputusan pembayaran dividen [8]. Karena pembayaran dividen menunjukkan arus kas keluar, makin besar posisi kas dan keseluruhan likuiditas perusahaan, maka makin besar kemampuan perusahaan untuk membayar dividen. Likuiditas perusahaan perbankan dapat diukur melalui rasio keuangan seperti cash ratio, Loan to Deposit Ratio (LDR), loan to asset ratio, investing policy ratio, banking ratio.

Pertumbuhan perusahaan selalu identik dengan aset pertumbuhan (baik aset fisik seperti tanah, bangunan, gedung, serta aset keuangan seperti kas, piutang, dan lain-lain). Paradigma aset sebagai indikator pertumbuhan merupakan hal yang lazim digunakan. Nilai total aset dalam neraca menentukan kekayaan perusahaan [19]. Sedangkan dalam mengukur pertumbuhan perusahaan, salah satu ukuran yang dapat digunakan adalah dengan menggunakan rasio pertumbuhan. Perusahaan yang mempunyai tingkat pertumbuhan yang tinggi akan mempunyai rasio pembayaran dividen yang rendah, sebaliknya perusahaan yang tingkat pertumbuhannya rendah akan mempunyai rasio yang tinggi. Pembayaran dividen merupakan bagian dari kebijakan dividen perusahaan [20].

\section{KESIMPULAN}

1. Variabel Likuiditas berpengaruh terhadap Dividend Payout Ratio (DPR) pada perusahaan perbankan yang terdaftar di Bursa Efek Indonesia tahun 2013-2017.

2. Variabel Growth berpengaruh terhadap Dividend Payout Ratio (DPR) pada perusahaan perbankan yang terdaftar di Bursa Efek Indonesia tahun 2013-2017 namun memiliki hubungan yang berlawanan arah dengan dividend payout ratio (DPR).

3. Variabel Likuiditas dan Growth secara bersama-sama berpengaruh terhadap Dividend Payout Ratio (DPR) ) pada perusahaan perbankan yang terdaftar di Bursa Efek Indonesia tahun 20132017. 


\section{SARAN}

1. Pihak perusahaan dalam usahanya dituntut untuk senantiasa menjaga keseimbangan antara pembayaran kewajiban dengan pembayaran dividen. Salah satu caranya adalah dengan membuat kebijakan mengenai jangka waktu pemenuhan kewajiban keuangan perusahaan baik jangka pendek maupun jangka panjangnya.

2. Untuk meningkatkan kepercayaan investor kepada perusahaan, sebaiknya pihak perusahaan yang memiliki tingkat laba tinggi, alangkah lebih baiknya jika membagi laba tersebut untuk melakukan pembayaran dividen kepada para investor dan sebagian lagi bisa digunakan untuk membiayai pertumbuhan perusahaan, sehingga kesejahteraan antara para investor dan juga proses pertumbuhan perusahaan senantiasa akan terjaga dengan baik.

\section{DAFTAR PUSTAKA}

[1] D. Z. Hamidi, “Analisis Jumlah Kebutuhan Dosen Tetap Di Perguruan Tinggi,” vol. 3, no. March, pp. 10-18, 2018.

[2] R. Ang, Buku Pintar Pasar Modal, 7th ed. Media Soft Indonesia, 2010.

[3] A. Martono and D. A. Harjito, Manajemen Keuangan. Edisi pertama. 2008.

[4] J. Hartono, Teori portofolio dan analisis investasi. 2008.

[5] E. F. Brigham and J. F. Houston, Fundamentals of financial management (Dasar-dasar Manajemen Keuangan), vol. 3, no. 3. 2007.

[6] S. Husnan, Dasar-dasar Teori Portofolio \& Analisis Sekuritas. UPP STIM YKPN, 2018.

[7] Kasmir, Analisis Laporan Keuangan. Jakarta: PT RajaGrafindo Persada, 2012.

[8] J. C. Van Horne and J. M. Wachowicz, Fundamentals of financial management. Pearson Education, 2005.

[9] C. H. Griffin, "Liquidity and Dividend Policy: International Evidence," Int. Bussines Res., vol. 3, no. 3, 2010.

[10] S. Murni and Andriana, "Pengaruh Insider Ownership Institutional Investor, Dividend Payments, dan Firm Growth Terhadap Kebijakan Utang Perusahaan.," J. Akunt. dan Bisnis, vol. 7, no. 1, pp. 15-24, 2007.

[11] J. B. Janifairus et al., "Pengaruh Return on Asset, Debt To Equity Ratio, Assets Growth, Dan Cash Ratio Terhadap Dividend Payout Ratio,” J. Adm. bisnis, vol. 1, pp. 161-169, 2010. 
[12] T. Darmadji and H. M. Fakhruddin, Pasar modal di indonesia edisi 3. 2011.

[13] S. Munawir, Analisa laporan Keuangan. Yogyakarta: Liberty, 2000.

[14] B. Riyanto, Dasar-dasar Pembelanjaan Negara. 2008.

[15] U. Sekaran and R. Bougie, Research Methods for Business: A Skill Building Approach, Seventh. West Sussex, United Kingdom: John Wiley \& Sons, 2016.

[16] P. Sugiyono, Metode Penelitian Kuantitatif, Kualitatif, dan R\&D. 2017.

[17] D. N. Baramuli, "Pengaruh Likuiditas Dan Profitabilitas Terhadap Devidend Payout Ratio Pada Top Bank Di Indonesia (Bri, Bank Mandiri, Bni Dan Bca),” J. Berk. Ilm. Efisiensi, vol. 16, no. 3, pp. 356-366, 2016.

[18] A. Y. et all. Effendi, "Pengaruh Return On Asset, Asset Growth, Sales Growth dan Debt to Equity Ratio Terhadap Dividend Payout Ratio,” J. Akunt. Univ. Bung Hatta, 2014.

[19] A. H. Prasetyo, Manajemen Keuangan bagi Manajer Non Keuangan. 2011.

[20] M. M. Hanafi and A. Halim, Analisis Laporan Keuangan, Edisi Keempat. 2009. 